\title{
Effect of Heat Stress on Reproductive Performance, Blood Biochemical and Physiological Parameters of Sows Following Mating
}

\author{
Suresh Kumar ${ }^{1,2}$, Champak Barman ${ }^{3}$, G. Kadirvel $^{1}$, G. Khargharia ${ }^{1}$, Geetima Barman ${ }^{4}$ and D.J. Rajkhowa ${ }^{5}$ \\ ${ }^{1}$ Division of Animal Production, ICAR Research Complex for NEH Region, Umiam, Barapani, Meghalaya, INDIA \\ ${ }^{2}$ Cattle Physiology and Reproduction Division, ICAR-Central Institute for Research on Cattle, Meerut, U.P., INDIA \\ ${ }^{3}$ Department of Veterinary Physiology, College of Veterinary Science, Assam Agricultural University, Khanapara, \\ Guwahati, Assam, INDIA \\ ${ }^{4}$ Assam State Rural Livelihood Mission, Morigaon, Assam, INDIA \\ ${ }^{5}$ ICAR-Research Centre for NEH Region, Nagaland Centre, Jharnapani, Medziphema, Nagaland, INDIA \\ *Corresponding author: C Barman; E-mail:drchampak80@gmail.com
}

Received: 01 Sep., 2020

Revised: 11 Oct., 2020

Accepted: 28 Oct., 2020

\begin{abstract}
The experiment was conducted with a total of 12 sows of different breeds (Pure Hampshire, Khasi local and Ghungroo) for evaluating the effect of heat stress on reproductive performance, blood biochemical and physiological parameters of sows following mating. The experiment was conducted at Livestock Production Farm, ICAR Research Complex for NEH Region, Umiam, Meghalaya-793103, India for a period of 3 months. The animals were divided into 2 groups viz. experimental and control groups consisting 6 sows in each. The animals of experimental group were kept in continuous exposure to direct sunlight daily for 6 hours (from 9 A.M. to 3 P.M.) up to 20 days following mating and after that, they were kept separately. The animals of the control group were also kept separately in normal condition in shaded room with temperature average $71.6^{\circ} \mathrm{F}$ following mating. The serum protein $(9.2 \pm 0.87 \mathrm{~g} / \mathrm{dl})$ and glucose values $(112.25 \pm 0.75 \mathrm{mg} / \mathrm{dl}) \&$ the physiological parameters like rectal temperature $\left(41.9^{\circ} \mathrm{C} \pm 0.10\right.$ per minute), respiration rate $(30 \pm 0.07$ breaths per minute) and heart rate $(82 \pm 0.15$ beats per minute) were significantly higher $(\mathrm{p}<0.05)$ in experimental group of animal than the control but the value recorded in relation to the litter size number $(5.97 \pm 0.19)$ at weaning was found to be significantly higher $(p<0.05)$ in control than that of the experimental group and serum cholesterol concentration $(116.65 \pm 0.05 \mathrm{mg} / \mathrm{dl})$ also increased significantly $(\mathrm{p}<0.05)$ in control group than that of the experimental.
\end{abstract}

\section{HIGHLIGHTS}

(O Heat stress reduces the reproductive performance of animals.

0 Heat stress causes alteration of blood biochemical and physiological parameters of animal.

Keywords: Heat stress, Protein, Glucose, Cholesterol

Pigs are particularly sensitive to heat stress because they lack functional sweat glands and despite decades of intense genetic selection, still have a thick layer of subcutaneous adipose tissue that acts as an effective insulation layer. Physiological signs of heat stress in pig include an increase in respiration rate, rectal temperature, pulse rate, reduction in feed intake and behavioral adjustments. Heat stress (HS) can be defined as a series of alterations in the physiology, metabolism and behaviour of animals exposed to high ambient temperature (Horowitz et al., 2004; Mayengbam and Tolenkhomba, 2015). It is well known that elevated temperature is a major factor responsible for reduced reproductive performance in pig which inhibits embryonic

How to cite this article: Kumar, S., Barman, C., Kadirvel, G., Khargharia, G., Barman, G. and Rajkhowa, D.J. (2020). Effect of heat stress on reproductive performance, blood biochemical and physiological parameters of sows following mating. J. Anim. Res., 10(6): 1015-1019. Source of Support: None; Conflict of Interest: None 
development and also responsible for variation of serum biochemical and physiological parameters (Hansen et al., 2001; Ross et al., 2015). Heat stress reduces embryonic survival by 30 to $40 \%$ during embryonic implantation (first 13 days post-mating) (Einarsson et al., 2008; Ross et al., 2015). Surprisingly, sows are rather tolerant of heat stress during mid-gestation (14 to 90 days post mating). Therefore, the present experiment was conducted in order to evaluate the effect of heat stress on reproductive performance and blood biochemical and physiological parameters of experimental and control groups of sows following mating.

\section{MATERIALS AND METHODS}

A total of 12 sows of different breeds (Pure Hampshire, Khasi local, Ghungroo) between $2^{\text {nd }}$ and $5^{\text {th }}$ lactation having no previous history of diseases were selected for the experiment. The experiment was conducted at Livestock Production Farm, ICAR Research Complex for NEH Region, Umiam, Meghalaya-793103, India for a period of 3 months (from May, 2013 to July, 2013). The animals were divided into 2 groups viz. experimental and control groups consisting 6 animals in each. The animals of the two groups were examined properly throughout the study period. The animals were given normal diet at morning and evening time \& water was given ad libitum. The animals of experimental group were kept in continuous exposure to direct sunlight daily for 6 hours (from 9 A.M. to 3 P.M.) up to 20 days following mating and after that, the animals were kept separately. The animals of the control group were also kept separately in normal condition in shaded room with temperature average $71.6{ }^{\circ} \mathrm{F}$ following mating. Blood $(5-7 \mathrm{ml})$ was collected from the anterior venacava of all the animals of both the groups on $0,7,14$ and 20 days of post breeding for estimation of serum total protein, glucose and cholesterol concentrations. Serum was separated within 8 hours of blood collection and centrifuged at $3000 \mathrm{rpm}$ for 10 minutes and stored at -20 ${ }^{\circ} \mathrm{C}$ until analysis. Serum protein, glucose and cholesterol concentrations were estimated as per the method described by Varley (1988). The physiological parameters like body temperature, respiration rate and heart rate were recorded at 15 days interval during the study period. During the study period, the average temperature, humidity and Temperature Humidity Index (THI) were also recorded as $74.88{ }^{\circ} \mathrm{F}, 81.67 \%$ and $73.45 \& 71.6{ }^{\circ} \mathrm{F}, 69.33 \%$ and 69.46 respectively for experimental and control groups of sows (Table 1). Temperature Humidity Index (THI) was calculated using the formula of Kelly and Bond (1971).

\section{STATISTICAL ANALYSIS}

Data obtained from the experiment were analysed statistically as per the method described by Snedecor and Cochran (2007).

\section{RESULTS AND DISCUSSION}

The conception rate (\%) of experimental and control groups of animal were recorded as $50 \pm 0.00$ and 83.33 \pm 3.98 respectively (Table 2 ). The conception rate of the experimental group was found to be significantly lower $(p<0.05)$ than that of the control group of animal. This might be due to insufficient hormone secretion (estrogen and progesterone) or due to having relation with the altered maternal recognition of pregnancy (Martins, 2010; Pennarossa et al., 2012) or might be attributed to inhibition of embryonic development and also due to their low sweating capacity, suffering from serious impairment of reproductive efficiency when moderately stressed (Nardone et al., 2006; Ross et al., 2015).

The litter sizes at birth (no.) were recorded as $5.5 \pm 0.25$ and $6.5 \pm 0.31$, respectively for experimental and control groups (Table 2). The value recorded in the animals of control group were found to be apparently higher as

Table 1: Meteorological data during the study period (from May, 2013 to July, 2013)

\begin{tabular}{llllllll}
\hline & \multicolumn{3}{c}{ Experimental group } & \multicolumn{3}{c}{ Control group } \\
\hline Month & Temperature $\left(\mathbf{~}^{\mathbf{0}} \mathbf{F}\right)$ & Humidity (\%) & THI & Month & Temperature ( $\mathbf{(}^{\mathbf{0}} \mathbf{\text { T) }}$ & Humidity (\%) & THI \\
\hline May & 73.51 & 86 & 72.38 & May & 71.06 & 65 & 68.70 \\
June & 75.15 & 78.42 & 73.80 & June & 70.70 & 69 & 68.67 \\
July & 75.99 & 80.6 & 74.16 & July & 73.04 & 74 & 71.00 \\
Average & 74.88 & 81.67 & 73.45 & Average & 71.6 & 69.33 & 69.46 \\
\hline
\end{tabular}


compared to that of the experimental group but analysis of variance revealed no significant differences between experimental and control groups of pig. This might be due to the lower level of progesterone concentrations in peripheral plasma in heat stressed pig during 0-19 days after mating which leads to the early embryonic mortality and ultimately causes reduced litter size at birth. Similar findings recorded in the present experiment were in close agreement with the earlier reports (Wildt et al., 1975; Tummaruk et al., 2004; Ross et al., 2017).

Table 2: Reproductive performance of experiment and control groups of sows following mating

\begin{tabular}{lll}
\hline Parameters & $\begin{array}{l}\text { Experimental } \\
\text { group }\end{array}$ & Control group \\
\hline $\begin{array}{l}\text { Conception rate (\%) } \\
\text { Individual body weight at } \\
\text { birth(kg) }\end{array}$ & $1.10^{\mathrm{a}} \pm 0.00$ & $83.33^{\mathrm{b}} \pm 3.98$ \\
$\begin{array}{l}\text { Litter size at weaning (no.) } \\
\text { Individual body weight at }\end{array}$ & $4.5^{\mathrm{a}} \pm 0.104$ & $1.3^{\mathrm{NS}} \pm 0.04$ \\
weaning (kg) & $9.25^{\mathrm{NS}} \pm 0.15$ & $9.97^{\mathrm{b}} \pm 0.19$ \\
\hline
\end{tabular}

a, b Means with different superscripts in a row differ significantly $(\mathrm{P}<0.05),{ }^{\mathrm{NS}}$ Non-significant.

The individual body weight $(\mathrm{kg})$ at birth was recorded as $1.15 \pm 0.06$ and $1.3 \pm 0.04$ respectively for experimental and control groups of pigs (Table 2). The values recorded in the present experiment were found to be non-significant between the experiment and control groups of animal. The present findings were in close agreement with the earlier reports (Tummaruk et al., 2004; Grela et al., 2005).

The litter sizes at weaning (no.) were recorded as $4.5 \pm$ 0.10 and $5.97 \pm 0.19$ respectively for experimental and control groups of animal (Table 2). The nos. of litter size of control group of animal recorded at weaning were found to be significantly higher $(p<0.05)$ than the values recorded in experimental group of animal. Significantly lower value recorded in experimental group might be due to environmental factors or bad mothering ability of the sows. The present findings were in close agreement with the earlier reports (Grela et al., 2005; Boma and Bilkel, 2006; Bloemhof et al., 2008; Ross et al., 2015).

The individual body weight $(\mathrm{kg})$ of the animals at weaning was recorded as $9.25 \pm 0.15$ and $9.75 \pm 0.218$ respectively for experimental and control groups (Table 2). Analysis of variance revealed no significant differences in respect of individual body weight at weaning between experimental and control groups of animal. The values recorded in the present experiment were in close association with the earlier report (Grela et al., 2005).

The serum total protein concentrations $(\mathrm{g} / \mathrm{dl})$ were found to be significantly higher $(\mathrm{p}<0.05)$ in experimental group of pig $(9.2 \pm 0.87)$ as compared to the value recorded in control group $(6.5 \pm 0.25)$ of animal (Table 3$)$. Significantly higher values recorded in experimental group of pig which might be due to stress causing rise in glucocorticoids of animal (Averos et al., 2007; Etim et al., 2014).

The serum glucose concentrations $(\mathrm{mg} / \mathrm{dl})$ recorded in the present experiment were as $112.25 \pm 0.75$ and $98.5 \pm 0.15$ respectively for experimental and control groups of animal (Table 3). Here the value recorded in the experimental group of animal were found to be significantly higher $(p<0.05)$ as compared to that recorded in the control group of animal. Significantly higher value recorded in experimental group of animal could be attributed to the increased adrenocortical hormones during moderate heat stress followed by mobilization of liver glycogen under the influence of increased adrenaline level (Etim et al., 2014).

Table 3: Serum protein $(\mathrm{g} / \mathrm{dl})$, glucose $(\mathrm{mg} / \mathrm{dl})$ and cholesterol concentrations $(\mathrm{mg} / \mathrm{dl})$ in experimental and control groups of sows following mating

\begin{tabular}{lll}
\hline Biochemical parameters & $\begin{array}{l}\text { Experimental } \\
\text { group }\end{array}$ & Control group \\
\hline Serum total protein $(\mathrm{g} / \mathrm{dl})$ & $9.2^{\mathrm{a}} \pm 0.87$ & $6.75^{\mathrm{b}} \pm 0.25$ \\
Serum glucose $(\mathrm{mg} / \mathrm{dl})$ & $112.25^{\mathrm{a}} \pm 0.75$ & $98.5^{\mathrm{b}} \pm 0.15$ \\
Serum cholesterol $(\mathrm{mg} / \mathrm{dl})$ & $93.07^{\mathrm{a}} \pm 0.20$ & $116.65^{\mathrm{b}} \pm 0.05$ \\
\hline
\end{tabular}

a, bMeans with different superscripts in a row differ significantly $(\mathrm{P}<0.05)$

The serum cholesterol concentrations $(\mathrm{mg} / \mathrm{dl})$ recorded in the present experiment were as $93.07 \pm 0.20$ and 116.65 \pm 0.05 respectively for experimental and control groups of pig (Table 3 ). Significantly lower values $(p<0.05)$ were recorded in experimental group of pig as compared to the value recorded in control group of pig which might be due to the incomplete carbohydrate metabolism leading to lower level of acetyl-Co A in blood circulation caused by the stressful conditions or might be due to dependency of 
the cholesterol level on the genotype of animal in relation to lipoproteins and the feed utilizing capacity of the animals (Pearce, 2011).

The rectal temperatures $\left({ }^{\circ} \mathrm{C}\right)$ of experimental and control groups of pig were recorded respectively as $41.9 \pm 0.10$ and $38.4 \pm 0.05$ (Table 4 ). The body temperature of experimental group of animal were found to be significantly higher $(p<0.05)$ than control group which might be attributed to the inability to acclimatize completely to effect of heat stress during the study period (Marple et al., 1981; Pearce, 2011).

The heart rate (beats per minute) were also found to be significantly higher $(\mathrm{p}<0.05)$ in experimental group of animal $(82 \pm 0.15)$ as compared to the value recorded in control group of animal $(70.1 \pm 0.72)$ (Table 4). The increase in heart rate of experimental group of pigs might be due to the bio-thermal mechanisms initiated to counteract the detrimental effects of increased body temperature (Patience et al., 2005).

Table 4: Effect of heat stress on physiological parameter of experimental and control groups of sows following mating

\begin{tabular}{lll}
\hline Physiological parameters & $\begin{array}{l}\text { Experimental } \\
\text { group }\end{array}$ & $\begin{array}{l}\text { Control } \\
\text { group }\end{array}$ \\
\hline Rectal temperature $\left({ }^{\circ} \mathrm{C}\right)$ & $41.9^{\mathrm{a}} \pm 0.10$ & $38.4^{\mathrm{b}} \pm 0.05$ \\
Heart rate (beats per minute) & $82^{\mathrm{a}} \pm 0.15$ & $70.1^{\mathrm{b}} \pm 0.72$ \\
$\begin{array}{l}\text { Respiratory rate (breaths per } \\
\text { minute) }\end{array}$ & $30^{\mathrm{a}} \pm 0.07$ & $15^{\mathrm{b}} \pm 0.32$ \\
\hline
\end{tabular}

$\mathrm{a}, \mathrm{b}$ Means with different superscripts in a row differ significantly $(\mathrm{P}<0.05)$.

The respiratory rate (breaths per minute) of experimental and control groups of pigs were recorded respectively as $30 \pm 0.07$ and $15 \pm 0.32$ (Table 4). The respiratory rate increased significantly $(\mathrm{p}<0.05)$ in experimental group than the value recorded in control group which might be attributed to an attempt by the animal to dissipate the excess body heat or as a means of enhancing evaporative heat loss (Lopez et al., 1991; Patience et al., 2005).

\section{CONCLUSION}

From the present study it can be inferred that no significant differences were found between the experimental and control groups of animal in respect of total litter size (no.) and individual body weight $(\mathrm{kg})$ at birth \& weaning. The serum protein $(9.2 \pm 0.87 \mathrm{~g} / \mathrm{dl})$ and glucose values $(112.25$ $\pm 0.75 \mathrm{mg} / \mathrm{dl}) \&$ the physiological parameters like rectal temperature $\left(41.9{ }^{\circ} \mathrm{C} \pm 0.10\right.$ per minute), respiration rate $(30 \pm 0.07$ breaths per minute) and heart rate $(82 \pm 0.15$ beats per minute) increased significantly $(p<0.05)$ in experimental group than the control group of animal but higher value $(\mathrm{p}<0.05)$ was observed in case of the litter size (no.) at weaning $(5.97 \pm 0.19)$ in control group than the experimental group and serum cholesterol concentration $(116.65 \pm 0.05 \mathrm{mg} / \mathrm{dl})$ also increased significantly $(\mathrm{p}<0.05)$ in control group than the experimental group of animal. The present work will precisely help the scientists and the researchers in expediting the ideas regarding effect of heat stress on reproductive performance, blood biochemical and physiological parameters of post breeding animals (pig).

\section{ACKNOWLEDGEMENTS}

The authors wish to extend their gratitude to the P.I., NICRA Project and Director, ICAR Research Complex for NEH Region, Umiam, Barapani, Meghalaya-793103, India for providing all necessary infrastructure facilities for carrying out the research works during the study period.

\section{REFERENCES}

Averos, X., Herranz, A., Sanchez, R., Comella, J.X. and Gosalvez, L.F. 2007. Serum stress parameters in pigs transported to slaughter under commercial conditions in different seasons. Veterinarni Medicina, 52(8): 333-342.

Bloemhof, S., Waaij, E.H.V., Merks, J.W. and Knol, E.F. 2008. Sow line differences in heat stress tolerance expressed in reproductive performance traits. J. Anim. Sci., 86: 3330-3337.

Boma, M.H. and Bilkel, G. 2006. Seasonal infertility in Kenyan pig breeding units. Onderstepoort J. Vet. Res., 73: 229-232.

Einarsson,S., Brandt,Y., Lundeheim, N. and Madej, A. 2008. Stress and its influence on reproduction in pigs: a review. Acta Veterinaria Scandinavica, 50: 1-8.

Etim, N.A.N., Williams, M.E., Akpabio, U. and Offiong, E.E.A. 2014. Haematological parameters and factors affecting their values. Agric. Sci., 2 (1): 37-47.

Grela, E.R., Czech, A. and Chachaj, R. 2005. Effect of L-carnitine diets on performance and blood metabolites in sows. J. Anim. Feed Sci., 14(1): 349-352.

Hansen, P.J., Drost, M., Rivera, R.M., Paula-Lopes, F.F., AlKatanani, Y.M., Krininger, C.E. and Chase, C.C. 2001. 
Adverse impact of heat stress on embryo production: causes and strategies for mitigation. Theriogenology, 55(1): 91-103.

Horowitz, M., Eli-Berchoer, L., Wapinski, I., Friedman, N. and Kodesh, E. 2004. Stress-related genomic responses during the course of heat acclimation and its association with ischemicreperfusion cross-tolerance. J. Appl. Physiol., 97: 1496-1507.

Kelly, C.F. and Bond, T.E. 1971. Bioclimatic factors and their measurement. A guide to environmental research in animals. Natl. Acad. Sci., Washington DC, pp. 7-92.

Lopez, J., Jesse, G.W., Becker, B.A. and Ellersieck, M.R. 1991. Effect of temperature on the performance of finishing swine: effects of a hot, diurnal temperature on average daily gain, feed intake and feed efficiency. J. Anim. Sci., 69: 1843-1849.

Marple, D.N., Nachreiner, R.F., Pritchett, J.F. and Kuhlers, D.L. 1981. The relationship of thyroxine secretion rate to growth of swine. J. Anim. Sci., 52: $500-508$.

Martins, C.A.M. 2010. Pig breeding in hot climate. Dissertation submitted to Universidade de Tras-os-Montes e Alto Douro, Vila Real, Portugal.

Mayengbam, P. and Tolenkhomba, T.C. 2015. Seasonal variation of hemato-biochemical parameters in indigenous pig: Zovawk of Mizoram, Vet. World, 8(6): 732-737.

Nardone, A., Ronchi, B., Lacetera, N. and Bernabucci, U. 2006. Climatic effects on productive traits in livestock. Vet. Res. Comm., 30: 75-81.

Patience, J.F., Umboh, T.J.F., Chaplin, R.K. and Nyachoti, C.M. 2005. Nutritional and physiological responses of growing pigs exposed to a diurnal pattern of heat stress. Livest. Prod. Sci., 96: 205-214.
Pearce, S.C. 2011. The effects of heat stress and nutritional status on metabolism and intestinal integrity in growing pigs. Graduate Thesis and Dissertations submitted to Iowa State University Ames, Iowa.

Pennarossa, G., Maffei, S., Rahman, M.M., Berruti, G., Brevini, T.A. and Gandolfi, F. 2012. Characterization of the constitutive pig ovary heat shock chaperone machinery and its response to acute thermal stress or to seasonal variations. Biol. Reprod., 87: 119-127.

Ross, J.W., Hale, B.J., Gabler, N.K., Rhoads, R.P., Keating, A.F. and Baumgard, L.H. 2015. Physiological consequences of heat stress in pigs. Anim. Reprod. Sci., 55: 1381-1390.

Ross, J.W., Hale, B.J., Seibert, J.T., Romoser, M.R., Adur, M.K., Keating, A.F. and Baumgard, L.H. 2017. Physiological mechanisms through which heat stress compromises reproduction in pigs. Mol. Reprod. Dev., 84: 934-945.

Snedecor, G.W. and Cochran, W.G. 2007. Statistical Methods. $8^{\text {th }}$ edn, Iowa State University Press, Ames Iowa.

Tummaruk, P., Tantasuparuk, W., Techakumphu, M. and Kunavongkrit, A. 2004. Effect of season and outdoor climate on litter size at birth in purebred Landrace and Yorkshire sows in Thailand. J. Vet. Med. Sci., 66(5): 477- 482.

Varley, H. 1988. Practical Clinical Biochemistry, $4^{\text {th }}$ edn., CBS Publishers and Distributors, 485, Bhola Nath Nagar, Shahdara, Delhi-110032, pp. 80 -309.

Wildt, D.E., Riegle, G.D. and Dukelow, W.R. 1975. Physiological temperature response and embryonic mortality in stressed swine. Am. J. Physiol., 229: 1471-1475. 
